\title{
DIE EENHEID VAN DIE KERK IN GEDRANG
}

\begin{abstract}
Authors:
Tanya van $\mathrm{Wyk}^{1}$

Johan Buitendag ${ }^{1}$
\end{abstract}

\begin{abstract}
Affiliations:
${ }^{1}$ Department of Systematic

Theology and Christian

Ethics, Univeristy of

Pretoria, South Africa
\end{abstract}

\section{Correspondence to:}

Tanya van Wyk

email:

tanya.vanwyk@up.ac.za

\section{Postal address:}

Department of Systematic

Theology and Christian

Ethics, Univeristy of

Pretoria, Lynwood Road,

Hatfield 0083, Pretoria,

South Africa

\section{Keywords:}

homosexuality;

ecclesiology; inclusive;

racism; unity; catholicity;

apostolicity

\section{Dates:}

Received: 16 July 2010

Accepted: 07 Sept. 2010

Published: 16 Nov. 2010

How to cite this article: Van Wyk, T. \& Buitendag, J., 2010, 'Die eenheid van die kerk in gedrang', HTS Teologiese Studies/ Theological Studies 66(1), Art. \#908, 9 pages. DOI: 10.4102/hts.v66i1.908

\section{This article is available} at:

http://www.hts.org.za

\section{Note:}

This article is a reworked version of a minidissertation entitled 'Die rol wat 'n ekklesiologie speel in die verstaan en hantering van homoseksuele persone met besondere verwysing na die NHKA', presented in partial fulfilment of the requirements for the degree of Master of Theology in 2009 at the University of Pretoria under the supervision of Prof. Dr Johan Buitendag as supervisor.

(C) 2010. The Authors. Licensee: OpenJournals Publishing. This work is licensed under the Creative Commons Attribution License.

\section{ABSTRACT}

The unity of the church in jeopardy

This article examines the possible influence that a church's understanding of ecclesiology could have on its approach to homosexual people, with special reference to the Netherdutch Reformed Church of Africa (NRCA). By referring to recent debates in the NRCA concerning the prominence the Church awards to the tenet of an 'ethnic church' ('volkskerk') in its ecclesiology, it is argued that the Church's understanding of the confession of the one, holy, apostolic and catholic church is not reflected in the NRCA's own ecclesiology and that this has direct implications for the Church's understanding and accommodation of homosexual people. It is concluded that if the Church maintains an inclusive character as it is meant in the Creeds, the Church has to design and incorporate models of being church that adhere to this character and the abovementioned confession.

\section{DIE KRISIS RONDOM HOMOSEKSUALITEIT EN DIE BYBEL}

Die huidige debat aangaande homoseksualiteit ${ }^{1}$ het die Christelike kerk voor ' $\mathrm{n}$ krisis te staan gebring (Rogers 2006:i; Dreyer 2004:176). Uit byna eindelose eksegetiese navorsing oor die interpretasie van Skrifgedeeltes (kyk Seitz 2000; Rogers 2006:70; Waetjen 1996; Masango 2002; Dreyer 1999; Geyser 2002:1659; Seow 1996:17-34; Germond 1997:211-232; Bellis 2002:93-122; vgl Dreyer 2004:179-81) volg dit dat daar oor die saak van homoseksualiteit ten minste een konklusie gemaak kan word, naamlik dat daar twee uiteenlopende denkstrome is wat direk teenoor mekaar staan wat albei vanuit die Bybel geregverdig word (Seitz 2000:177). Die een veroordeel homoseksualiteit op grond van Bybelse getuienis; die ander bepleit ' $n$ inklusiewe benadering wat homoseksuele persone aanbetref, ook op grond van Bybelse getuienis (Dreyer 2004:177). Hierdie diskoers oor eksegetiese resultate het die debat aangaande homoseksualiteit by 'n impasse gebring.

In hierdie artikel word nie eksegese gedoen aangaande die hoofsaaklik vyf en in sommige gevalle agt, Skrifgedeeltes (vgl Rogers 2006:70; Dreyer, T.F.J. 1999; Geyser 2002:1659; Masango 2002; Waetjen 1996) waaroor gedebatteer word nie. ${ }^{2}$ Soos reeds genoem, het verskeie publikasies al die eksegetiese navorsingsresultate aangetoon en op grond daarvan tot uiteenlopende gevolgtrekkings gekom. Dreyer (2004:175-181) het aangetoon dat hierdie uiteenlopende (meestal botsende) gevolgtrekkings uit ' $n$ verskil in Skrifverstaan voortvloei.

Hierdie artikel ondersoek die moontlikheid dat ' $n$ ander saak as Skrifverstaan en die interpretasie van tekste die kerk se verstaan en hantering van homoseksuele persone beïnvloed. Hierdie moontlikheid blyk uit bepaalde onlangse ontwikkelinge in die debat onder verskeie kerklike denominasies aangaande die verstaan en hantering van homoseksuele persone.

Nadat dit aan die Nederduitse Gereformeerde Kerk (NGK) se gemeente in Moreletapark bekend geword het dat Johan Strydom homoseksueel georiënteerd is, hy gevolglik afgedank is en 'n hofgeding teen die gemeente aanhangig gemaak het, het die gemeente en hul leierskap soos volg gereageer:

- Dat daar geen probleme sou gewees het nie as mnr Strydom 'n homoseksuele oriëntasie gehad het, maar dit nie uitgeleef het nie.

- Dat ouderlinge en diakens in die NGK gay mag wees; hulle mag net nie hul homoseksualiteit uitleef nie.

- Dat ' $n$ homoseksuele oriëntasie nie sonde is nie, maar dat die beoefening daarvan wél sonde is.

(Craffert 2008:11)

In die Nederduitsch Hervormde Kerk van Afrika (NHKA) was die debat aangaande die verstaan en hantering van homoseksueel georiënteerde persone tydens die 67ste (2004) en die 68ste (2007) Algemene Kerkvergaderings (AKV) op die voorgrond. In die agenda van die 67ste AKV en in twee afsonderlike beskrywingspunte van die agenda van die 68ste AKV (sien onder) wat in een besluit tydens die vergadering saamgevoeg is, word onder andere die volgende stellings aangetref:

- 'Homoseksuele verbintenisse moet nie verwar word met ondersteunende vriendskapsverhoudings sonder' seksuele aksente 'tussen mense van dieselfde geslag nie' (eie beklemtoning).

- ' "n Geïsoleerde homoseksuele oriëntasie sonder' homoseksuele aktiwiteit 'word nie afgekeur nie'. Dieselfdegeslag-seks 'binne so ' $n$ verhouding, met wat daarmee saamgaan, is egter nie aanvaarbaar nie ...' (eie beklemtoning).

- Dit is ook foutief om die verskoning vir homoseksualisme voor te hou waar die gene die skuld kry omrede die persoon wat hieraan onderwerp is, 'daar niks aan kan doen nie'. 'n Alkohol misbruiker of habituele winkeldief of owerspelige mens of leuenaar of verskeie ander gedragsafwykende persone kan dieselfde soort verskonende argument opwerp om so aanvaarding te probeer vind ...

(NHKA 2004:392-393)

1.Die term 'homoseksualiteit' verwys in hierdie studie na die seksuele oriëntasie van die persoon sowel as die fenomeen. Vir 'n meer breedvoerige uiteensetting van die geskiedenis van die gebruik van dié term as fenomeen én as oriëntasie, vergelyk Foucault ([1978] 1990).

2.Dit is Genesis 19:1-29, Rigters 19:1-30, Levitikus 18:22, Levitikus 20:13, 1 Timoteus 1:9-10, Romeine 1:26-27 en 1 Korintiërs 6:9-11. 
en:

- 'Persone met 'n homoseksuele' oriëntering het die verantwoordelikheid om hulle te weerhou van homoseksuele gedrag 'net soos alle ander mense ten opsigte van hulle gebroke menslike natuur selfbeheersing moet beoefen' (eie beklemtoning).

- 'Die Kerk bevestig dat homoseksueel georiënteerde persone wat' selibaat 'lewe, tot die ampte van die Kerk toegelaat word' (eie beklemtoning)

(NHKA 2007a:47-48)

Ook in die Verenigende Gereformeerde Kerk (VGK) het daar ontwikkelinge in die debat aangaande homoseksualiteit plaasgevind. Volgens Kritzinger (2008) het die Belydenis van Belhar nog altyd aan die VGK hoop en rigting gegee. Dit kan gestel word dat dit die VGK se selfbelyde ekklesiologie weergee. In 2008 is die VGK se verslag oor hul studie oor homoseksualiteit by die Nasionale Sinode bekendgemaak. Daar het 'n hewige debat ontstaan rondom die verband tussen die implikasies van die verslag en die kontekstualisering en verkonkretisering van die Belydenis van Belhar. Op grond van die Belydenis het Allan Boesak sekere aanbevelings gedoen, wat onder meer 'n volledige aanvaarding van homoseksuele lidmate, homoseksuele predikante, homoseksuele huwelike en die aanneming van kinders deur homoseksuele egpare ingesluit het (Jackson 2008b). Hierdie voorstel is egter met hewige teenkanting begroet, wat uiteindelik gelei het tot prof. Boesak se bedanking uit alle poste waarin hy as verteenwoordiger van die VGK verkies is.

Vanuit hierdie enkele beskrywings blyk dit dat telkens as die verstaan en hantering van homoseksuele persone ter sprake kom, die voorwaardes vir deelname aan en opname in die kerklike gemeenskap ook ter tafel gebring word. Dít blyk daaruit dat homoseksuele persone se deelname aan en opname in die kerklike gemeenskap telkens met hulle selibaat-wees verbind word. Dit blyk verder daaruit dat die verkonkretisering van die VGK se selfbelyde ekklesiologie slegs problematies geword het toe dit op die verstaan en hantering van homoseksuele persone toegepas is. Die doel van hierdie artikel is om te toon dat die eie aard en identiteit van 'n kerk, soos dit in die ekklesiologie uitgedruk word, 'n invloed op die verstaan en hantering van homoseksuele persone het. Dít sal gedoen word met spesifieke verwysing na die NHKA.

\section{DIE AARD EN OMVANG VAN DIE KERK}

Aangesien hierdie artikel die moontlikheid ondersoek dat die ekklesiologie die kerk $^{3}$ se verstaan en hantering van homoseksuele persone beïnvloed, veral wat voorwaardes vir deelname aan en opname in die geloofsgemeenskap (die kerk) betref, moet bepaalde opmerkings eers oor die aard (wat) en die omvang (wie) van die kerk gemaak word.

\section{Die aard van die kerk}

Die Belydenis van die Niceano-Constantinopolitanum van 381 $\mathrm{nC}$ verklaar dat die kerk een, heilig, algemeen en apostolies is. Verskeie teoloë is dit eens dat hierdie vier kenmerke, of notae,

3.In die Nuwe Testament is daar geen eenduidige definisie van die begrip 'kerk' nie. Ekklesia word gebruik om onder andere na die universele kerk (Gezamtkirche, Kirche en Kirche Gottes) (Matt 16:18 en 1 Kor 12:28) en die lokale gemeente (Ortskirche en Lokalkirche) te verwys. Ekklesia word ook gebruik om die Versammlung der Christen zur Feier des göttlichen kultus aan te dui (Tofana 2005.35. vgl Van Wyk \& Chit 2008). Laasgen ( gebruik Paulus die enkelvoud sowel as die meervoud as hy van hierdie 'kerk' praat, met die bedoeling dat albei in direkte kontinuïteit met die samekoms (assembly) van Israel is en dat albei na die samekoms (gemeente) van God verwys. Die 'kerk' en die 'kerke' is dieselfde samekoms van een en dieselfde volk van God (Dunn 2008:13). Waa daar dus in hierdie artikel na 'kerk' verwys word, word die universele kerk bedoel, tensy daar spesifiek na die NHKA, NGK of VGK verwys word. Waar 'Kerk' met ' hoofletter verskyn, verwys dit na die NHKA as eienaam.

4.Die Nederlandse Geloofsbelydenis beaam die Belydenis van die Apostolicum wat betref die een, heilige, katolieke en Christelike kerk (artikel 27), maar voeg daaraan toe dat die ware kerk gevind kan word waar die Woord suiwer verkondig word die sakramente bedien word en die tug uitgeoefen word (artikel 29) (vgl Jonker die sakram
1994:70). die karaktertrekke van die kerk is (vgl Barth 1949:142; Moltmann 1993:337; Küng [1968] 2001:269; Kärkkaïnen 2002:79; Buitendag 2008:126).

As die legitimiteit van hierdie tekens as karaktertrekke van die aard van die kerk egter oorweeg word, dan moet die vraag na die mate van hul lewendige verwesenliking ook gevra word (Küng [1968] 2001:266). Daar moet beoordeel word of hierdie tekens gelééf word. Dit gaan nie oor tekens wat die kerk het nie, maar oor ' $\mathrm{n}$ aard wat die kerk is. By die oorweging van hierdie sake, moet ook die imperatief daarvan aangehoor word (Küng [1968] 2001:269). Dit moet as taak en opgawe van die kerk verstaan word (Botma 1996:159) en nie as die idee of ideale vorm van die kerk voorgehou word nie. Küng beklemtoon dat die ware essensie van die kerk nooit net ' $n$ idee kan wees nie ([1968] 2001:270). Ook Karl Barth (1949:142) verklaar dat die ware aard van die kerk ' $n$ handeling is; ' $n$ dinamiese gebeure; een wat in die geskiedenis plaasvind en 'n bepaalde historiese vorm het.

Moltmann (1993:337) verklaar dat as die kerk se ontstaan en bestaan op grond van die werking van Christus is, dan is die kerk se eienskappe juis ook die eienskappe van Christus se werking. Die erkenning van die een, heilige, katolieke en apostoliese kerk is dan die erkenning van die verenigende, heiligende, komprehensiewe en opdraggewende heerskappy van Christus (Moltmann 1993:338). Daarom is hierdie vier dimensies geloofsuitsprake. Die heil in Christus is die wese van die kerk. Hierdie dimensies verkry sin en betekenis in die kragveld van die Heilige Gees. Aangesien die kerk 'n gawe van Christus en die Heilige Gees is (kyk Hand 15:8, 28:1; 1 Kor 12:3, 12; Ef 3:16-19), is die dimensies van die kerk juis ook die karakter van die kerk. Hierdie karakter wat aan geloof en hoop geken word, moet tot uitdrukking gebring word en in etiek (optrede) oorgaan. Die legitimiteit van die dimensies kan ook hieraan gemeet word (Moltmann 1993:339; vgl Van Wyk \& Buitendag 2008:1450).

Die karaktertrekke wat die aard van die kerk weerspieël, kan nie anders as om voluit sigbaar te wees nie - anders word daar in 'n Platonistiese utopia verval (Van Aarde 1987; Küng [1968] 2001; Pelser 1994; Buitendag 2006). Die gedagte van die kerk wat 'n onsigbare grootheid is, met bepaalde ideale kenmerke van hoe dit moet lyk, voldoen nie aan die konkrete karakter van die kerk hier en nou nie. Dit voldoen ook nie aan die 'statements of action' nie, wat Moltmann noem as hy oor die vier kenmerke (dimensies) van die kerk praat (Moltmann 1993:342).

Gevolglik lê die eenheid van die kerk in die wyse waarop Christus mense in liefde bymekaarbring. Omdat die kerk in Christus een is, is die kerk veronderstel om een te wees. Eenheid van die kerk kan nie verstaan word asof dit afgehandel en onsigbaar is nie (Buitendag 2007:5). Eenheid gebeur en so word dit sigbaar. Dit móét ook gebeur.

Die heiligheid van die kerk lê in Christus se heiligheid en die manier waarop Hy sondaars verlos (Moltmann 1993:338). Om hierdie rede kan die heiligheid van die kerk ook nie verstaan word asof dit die kerk afsonder en isoleer nie (Buitendag 2007:5).

Die katolisiteit van die kerk lê in Christus se onbegrensde heerskappy en daarom moet die kerk in elke tyd en op elke plek Christus se heerskappy konsekwent sigbaar maak en uitnodigend en inklusief wees (Moltmann 1993:338). Die katolisiteit van die kerk maak die plaaslike kerk en die lede van die kerk sensitief teenoor ander lede en teenoor kerke van ander tye en ander plekke (Buitendag 2007:5). Dit maak egter ook die kerk sensitief vir die verskeidenheid van die belewing van spiritualiteit en godsdiensbeoefening binne ' $n$ bepaalde kerk (plaaslike gemeente).

Die apostolisiteit van die kerk moet in die raamwerk van die sending van Christus en die Heilige Gees verstaan word (Moltmann 1993:338). Die sending van die kerk lê in die wese van God: '... Mission is not primarily an "activity" of the church, 
but an "attribute" of God. God is a missionary God' (Bosch 1991:390; oorspronklike beklemtoning); 'it is the summing-up of all things in Christ' (Newbigin 1952). Soos God die Vader sy Seun gestuur het, so stuur die Seun sy dissipels en so word ons vandag gestuur. Dus is 'gestuurdheid' 'n opdrag aan alle gelowiges. Daarom kan die apostolisiteit van die kerk nie as 'n sydelingse taak verstaan word wat die kerk teenoor uitgelese groepe verrig nie (Buitendag 2007:5).

Augustinus (contra Cresconium, IV.xxi.26; in Oevres de Saint Augustin, vol. 31, in Finaert 1968:522-524) verklaar dat die kerk 'n corpus permixtum is; 'n gemeenskap wat tegelyk sondig en geregverdig is. Dit volg noodwendig dat hierdie dimensies indikatiewe en imperatiewe en gevolglik 'n eksistensiële saak vir kerkwees is. Dít het implikasies vir die omvang van die kerk, naamlik wie op grond waarvan by die geloofsgemeenskap ingesluit word.

\section{Die verbondsteologie en die kinderdoop as studiegeval vir die omvang van die kerk}

In die Ou Testament was die begrip verbond tekenend van 'n wedersydse verhouding tussen Jahwe en Israel (Eichrodt 1961:39). Die voorwaardes en bepalings van hierdie verhouding is egter deur Jahwe alleen vasgestel. Volgens Breytenbach (1984:8) het die begrip 'verbond' 'n verhouding uitgedruk waarin Jahwe, synde die meerdere, Israel, synde die mindere, Jahwe verbind deur self ' $n$ onderneming te maak en/of aan die mindere verpligtinge op te lê. In dié sin is Jahwe se genade in hierdie binding en toenadering sterk beklemtoon. Daarom word daar na die verbond tussen God en Abraham as die genadeverbond verwys (Engelbrecht 1983:2) en word die ander verbonde waarvan daar in die Ou Testament sprake is, naamlik die verbonde met Noag (Gen 9:1), Pinehas (Num 25:10) en Dawid (2 Sam 7:5), terugwerkend verbind aan en beskou as 'n voortsetting van, die verbond met Abraham (Breytenbach 1984:9; vgl Eichrodt 1961).

Verbondsluiting tussen Jahwe en Israel is met verbondstekens bekragtig. Die verbondsteken van die Noagverbond was die reënboog, maar die verbondsteken van die Abrahamverbond, oftewel die genadeverbond, was die besnydenis (Gen 17) (Breytenbach 1984:8; Van Aarde 1984:38). Hierdie tekens was 'n vorm van identifikasie; die teken dat iemand tot die verbond behoort. Dit was egter ook meer as dit: Dit was die verbond self - 'n teken van die realiteit van die verbond; 'n teken wat ook herinner.

In Jeremia 31:31-34 word gelees van 'n nuwe verbond, wat ' $\mathrm{n}$ voortsetting was van die ewige genadeverbond met Abraham. Volgens Hebreërs 10:16 is Jesus Christus die Middelaar van die nuwe verbond en op grond van Galasiërs 6:16 poneer König (1983; vgl Van Aarde 1984:38) dat die heilsbeloftes van God se ewige genadeverbond met Abraham ook vir die Nuwe-Testamentiese volk van God dieselfde bly. Van Aarde (1984:53) betoog dat twee Ou-Testamentiese verwysings na God se verbond belangrik was in die Nuwe-Testamentiese kerk se teologieë, daarom is dit daarin opgeneem en geïnterpreteer. Dit was die uitdrukking nuwe verbond (Jer 31) en die uitdrukking bloed van die verbond (Eks 24). In Matteus 26:26-29 verklaar Jesus tydens die maaltyd net voor sy kruisiging dat sy bloed die verbond beseël en dat sy bloed vir die vergifnis van baie gegiet sal word. In die uitdrukking 'nuwe wyn in nuwe sakke' in Matteus 19:14-19 dui die nuwe wyn op die verkondiging van die heerskappy van God, soos dit in die lewe en die werk van Jesus beliggaam word (Buitendag 2008:343), ook wat die nuwe verbond betref (vgl Mark 1:27 se 'nuwe leer' en Luk 22:20 se 'nuwe verbond'). Die inhoud van die koninkryk is Jesus self. Dít word in genade ontvang (vgl Matt 25:34). Volgens König (1983:47 ) is dieselfde begrippe wat in die Ou Testament met betrekking tot Israel (en dus die ou verbond) gebruik is, in die Pauliniese briewe op die kerk toegepas, naamlik 'heiliges', 'uitverkorenes', 'geliefdes' en 'geroepenes'. Ook Küng ([1968] 2001:115) verklaar dat die kerk die uitdrukkings wat in die Ou Testament op Israel van toepassing was, op sigself van toepassing maak en dat gelowiges hulself nie noodwendig Christene nie, maar volk van God genoem het.

Die enigste verskil tussen die ou verbond en die nuwe verbond sou die teken wees: die besnydenis as teken van die ou verbond en die doop as teken van die nuwe verbond.

Schlink (1972:135) bring die legitimiteit van die kinderdoop in verband met die verstaan van die werking van die sola gratia van God en dus die genadeverbond. Laasgenoemde het egter vir Karl Barth die meeste gewig gedra in sy beswaar teen die kinderdoop (Barth 1947:3-48). Hy verklaar in verband met die doop:

Die Taufe ... ist aber nicht Gnadenträger, nicht Gnadenmittel, nicht Instrument der Gnade. Die Taufe antwortet auf das eine 'Mysterium', das eine 'Sakrament', der Geschichte Jesu Christi, seiner Auferstehung, der Ausgiessung des Heiligen Geistes: sie selbst ist aber kein Mysterium, kein Sakrament.

(Barth, KD IV, 4, 112; kyk König 1971:44; vgl Van Aarde 1984:35)

Volgens hom is die doop ' $n$ getuienis van die genade van God en dui die doop gevolglik die begin van die mens se respons op daardie genade. Aangesien kinders nog nie in staat is om ' $n$ betekenisvolle respons te maak nie, kan die kinderdoop nie geregverdig word nie. Dit wil voorkom of Barth die uitwerking van die doop aan die hand van die mens se reaksie op God se genade meet.

Hierteenoor verklaar Schlink (1972:140) dat die reddende aktiwiteit van God nie afhanklik is van die mens se handelinge nie. Die verband tussen die genadeverbond en die kinderdoop is juis dat die karakter van die verbond vanuit die wese van God bepaal word en nie vanuit die wese van die mens wat sondaar is nie (Visser 1958:58). In die doop is die mens die ontvanger van die genade; nie die inisieerder of die katalisator nie. Die grondslag van die handeling van die kinderdoop is te vinde in die oortuiging dat God deur die doop aan kinders genade betoon; hulle sy eiendom maak; hulle deur die Heilige Gees van die oorheersing van sonde na die lewe van kinders van God verplaas. Die essensie van die kinderdoop is dus juis dat (omdat babas en nie volwassenes nie gedoop word) die genade van God, waarvan die doop 'n teken is, op geen wyse deur die handelinge en besluite van mense verdien kan word nie.

Hierdie gedagtes is die voortsetting van gedagtes aangaande die verbond van God wat God met die mens sluit en wat op God se aktiewe en willekeurige ingryping in die mens se geskiedenis en in mense se lewens dui.

As dit gestel word dat die doop by uitstek die teken is dat die mens tot die gemeenskap van gelowiges behoort; dat die mens daardeur onomkeerbaar lidmaat van die kerk word en dat ' $n$ sentrale funksie van sakramente (aldus Luther en Zwingli; kyk McGrath 2001:519) die versekering aan gelowiges is dat hulle werklik deel is van die liggaam van Christus, volg dit dat die sola gratia, soos in die solus Christus verteenwoordig, insluiting by die geloofsgemeenskap moontlik maak en dit konstitueer. Dit word uiteraard gekomplementeer deur die sola fide, maar die volgorde is belangrik: Die persoonlike geloof van die persoon veroorsaak nie die doop nie (die doop is nie 'n geloofsbelydenis nie); eerder is dit die doop wat tot hernieude geloof lei:

Taken into Christ's service as the vehicle for His rule, the church approaches the individual, embraces him with the love with which Christ has loved her, gives birth to the new person, and bears and nourishes him so that he may grow in the understanding of faith and likewise become and instrument of the Christ who is present and active. This understanding of the church forbids looking only at what the baptized may or may not be able to do in the moment of Baptism.

(Schlink 1972:158) 
Dus word dit gestel dat die aard van die verbond en die verband daarvan met die kinderdoop en spesifiek die doop van babas noodwendig die inklusiewe aard van die kerk beklemtoon en terselfdertyd die omvang van die kerk bepaal. Indien die imperatiewe aard van die kerk se dimensies in die lig van die verbond en die kinderdoop verstaan word, beteken die belydenis van die kerk as een, katoliek, heilig en apostolies dat alle gedooptes deel is van die geloofsgemeenskap. Die akkommodasie van die geloofsgemeenskap mag nie die inklusiewe aard van die verbond kompromitteer nie (Küng [1968] 2001:15-132).

Ten slotte kan dit hier gestel word dat hierdie afdeling die diskrepansie in die NHKA se ekklesiologie blootlê: enersyds wil die Kerk verbondskerk wees wat nie menslike prestasie nie, maar Goddelike genade konstitutief vir kerkwees maak; andersyds wil die Kerk die etiek (selibaat-wees) van homoseksueel georiënteerde mense deurslaggewend beskou.

\section{DIE NHKA SE EKKLESIOLOGIE}

Die NHKA se verstaan van kerkwees, oftewel ekklesiologie, word gevind in die Kerk se eie belydenis aangaande die Kerk se aard en identiteit, naamlik dié van volkskerk (Ordereël 1 en 4 van die NHKA se Kerkorde; NHKA 1997). Laasgenoemde selfbelyde aard en identiteit blyk ook uit die Kerk se verhoudings met ander kerke.

Ná die Tweede Wêreldoorlog het die debat oor die NHKA as volkskerk; Artikel III van die vorige Kerkwet, wat lidmaatskap van die NHKA tot wit mense beperk het, sowel as die bestaan van twee afsonderlike Hervormde kerke wat etnies gerig was, die geskiedenis van die NHKA oorheers (Dreyer 2006:1337). ${ }^{5}$

Die eerste breuk met ekumeniese liggame het plaasgevind met die Cottesloe-beraad van die Wêreldraad van Kerke wat in 1960 na aanleiding van die gebeure by Sharpeville plaasgevind het en waar lidkerke gevra is om Apartheid as strydig met die evangelie te veroordeel. Die Afrikaanse kerke en spesifiek die NHKA, het geweier (Dreyer 2006:1356). Die AKV van die NHKA besluit gevolglik tydens die sitting van 1961 om die Kerk se lidmaatskap van die Wêreldraad van Kerke op te sê.

In die Kommissie van die AKV se Herderlike Skrywe 1973 word die NHKA se volkskerklike denke as teologiese begronding van afsonderlike ontwikkeling (Apartheid) en aparte volkskerke as 'n Skriftuurlike beginsel aangebied. Dit word onomwonde gestel dat die NHKA sigself, te midde van ander kerke, deur Artikel $I I I^{6}$ van die Kerkwet van 1951 wil identifiseer (NHKA 1973:2). Daarin is ' $n$ lewensoortuiging vervat, naamlik die Hervormde Kerk se uitsluitlike verbondenheid met die Afrikanervolk. Dit was reeds met hierdie skrywe duidelik (en is ook so gestel) dat ekumeniese liggame nie as dienlike instrumente vir egte ekumeniese kontak beskou is nie.

Met die sitting van die World Alliance of Reformed Churches (WARC) te Ottawa in 1982 vra die WARC van die NHKA 'n uitspraak teen Apartheid. In 'n skerp bewoorde verklaring weier die Kommissie van die AKV egter om dit te doen. Tydens die AKV van 1986 word die dokument getiteld 'Kerk en Wêreld 2000' aanvaar as die kulminasie van 'n ondersoek na die omstandighede waarin die NHKA se roeping en taak in die daaropvolgende twee dekades uitgeleef sou word. Dit was in baie opsigte die NHKA se antwoord op die resolusie van die

5.Vir 'n oorsig oor die oorsprong van die NHKA se volkskerklike denke, kyk Van Wyk en Buitendag (2008)

6.Hierdie artikel het gelui: 'Die Kerk, bewus van die gevare wat blank en nie-blank vir altwee groepe inhou, wil geen gelykstelling in sy midde toelaat nie, maar beoog die stigting van eie volkskerke onder die verskillende volksgroepe, in die oortuiging dat aldus die bevel van die Here - 'maak dissipels van alle nasies' (Matt 28:19), die bes ' nie geskaad sal word nie. Tot die Nederduitsch Hervormde Kerk van Afrika behoort daarom net blanke persone' (NHKA 1951). 1982-vergadering van die WARC, waarin Apartheid as sonde en die teologiese fundering daarvan as dwaalleer veroordeel word (Dreyer 2006:1353). In hierdie dokument staan die volkskerklike interpretasie wat die NHKA met kerkwees verbind, weereens op die voorgrond. Die NHKA is eerste vir die Afrikaner en daarna en deur die Afrikaner vir al die ander. Dit word verklaar dat hierdie die konteks is waarin die NHKA se roeping verstaan word (NHKA 1985:5). Só word die NHKA se steun vir die beleid van afsonderlike ontwikkeling ook verdedig (NHKA 1985:6667).

Wat die verhouding tussen die NHKA en ander denominasies, susterkerke of dogterkerke betref, word dit onomwonde gestel dat daar geen verwagtinge gekoester word van kontak met kerke wat die 'ekumeniese teologie' aanhang nie (NHKA 1985:7). Met betrekking tot lidmaatskap van ekumeniese organisasies word verklaar dat dit nie vir die NHKA moontlik was om met " $n$ behoud van 'n skoon gewete langer lid daarvan [te kon] bly nie' (NHKA 1985:7). Trouens, in die dokument word ook weer aangetoon dat die NHKA sterk bedenkinge oor ekumeniese organisasies het, aangesien die NHKA iets van sigself moet prysgee as die Kerk deel van so 'n organisasie sou wees (NHKA 1985:12). Volgens Van der Merwe (1990:676) word daar met soveel woorde erken dat die NHKA vir geen agtenswaardige ekumeniese organisasie aanvaarbaar is óf enige sodanige organisasie aanvaarbaar vind nie. Die teologiese implikasies van hierdie toedrag van sake word glad nie in die dokument beredeneer nie en die redes waarom dit tot op daardie punt ontwikkel het, is nie diepgaande nie (Van der Merwe 1990:676). Dit word baie duidelik gestel dat die NHKA slegs betrokke sal raak waar die Kerk teologies tuis kan wees en waar dit teologies ' $n$ bydrae kan lewer.

Uit die daaropvolgende Herderlike Skrywe van 1990 word dit duidelik dat die NHKA se onkritiese identifisering van kerk en volk toenemend problematies geword het (Dreyer 2006:1354). In teenstelling met die vorige belangwekkende en belydenisagtige dokumente van en deur die NHKA, word daar in hierdie skrywe geen uiteensetting van die NHKA se Skriftuurlike begronding en verdediging van afsonderlike ontwikkeling en Artikel III aangetref nie. Sending na ander volke word eerder as die belangrikste roeping van die Kerk beklemtoon (NHKA 1990:11). Ten spyte hiervan word die gedagtes van Kerk en Wêreld 1985 herhaal, naamlik dat die NHKA in die eerste plek 'n kerk vir die Afrikaner is en deur middel van die apostolaat ook n kerk vir al die nasies wil wees. Die NHKA oordeel steeds dat die gestalte van die volkskerk die beste wyse is waarop die kerk die apostolêre opdrag kan uitvoer.

Wat met die eerste oogopslag nie na ' $n$ wesensaak in die NHKA gelyk het nie, blyk toe wél een te wees. Dít word duidelik met die goedkeuring van die nuwe Kerkorde in 1997. In Ordereël 1 van die Kerkorde word die Kerk as ' $n$ 'heilige volk' beskryf en in Ordereël 4 word die Kerk beskryf as:

'... 'n volkskerk met ' $n$ eie kerklike kultuur, geskiedenis, taal en
tradisie wat geroepe is tot die verkondiging van die evangelie van
Jesus Christus aan die Afrikanervolk en tegelyk aan alle mense.'

(NHKA 1997:69, eie beklemtoning)

Hierdie frase is op voorstel van die dogmatikus J.H. Koekemoer tydens die AKV as kompromis aan die Kerkorde toegevoeg. Deur hom op Karl Barth te beroep, het die Nuwe-Testamentikus A.G. van Aarde teen die kompromisvoorstel beswaar gemaak. Hy het die AKV versoek om nie in die Kerkorde 'n partikuliere apostolaat te verwoord nie en die AKV daarop gewys dat die toekoms sal leer dat lidmate die verwysing na volkskerk op 'n natuur-teologiese wyse as verburgerlikte teologie kan misbruik. Só sal die NHKA dus nie die toets om waarlik vir alle mense kerk te wees, slaag nie. ${ }^{7}$

Om die neweskikkende stelling 'aan Afrikanervolk en aan alle mense' in perspektief te stel, kan daar word op die kerkregtelike

7.Hierdie opmerking is nie genotuleer nie. Bevestiging daarvoor is mondelings deur betrokkenes betuig. 
verskil tussen 'n Ordereël en ' $n$ Ordinansie. Ordereëls is 'wesenlike sake' en Ordinansies die 'praktiese maatreëls' vir die uitvoering van sodanige wesenlike sake (Pont 1981:6-15). 'n Ordereël dra soveel gewig dat dit volgens Ordereël 10.1(iii) slegs deur ' $n$ tweederdemeerderheid stemme gewysig kan word (NHKA 1997:112). 'n Ordereël dra dus aansienlik meer gewig as 'n Ordinansie. Dat die NHKA in 'n Ordereël bely dat die Kerk 'n volkskerk is, dui dus daarop dat die NHKA die 'volkskerk' as 'n wesensaak sien; dit so verskans en dat die begrip 'volkskerk' die wese van die kerkwees van die NHKA beskryf en nie net die praktiese uitvoering van hierdie kerkwees nie.

In Junie 2006 het die WARC die NHKA besoek. Hierdie besoek het uit die NHKA se aansoek in 2005 (in opdrag van die AKV 2004) om hertoelating tot die WARC voortgevloei. Die WARC het gevolglik besluit om ' $\mathrm{n}$ feitesending na Suid-Afrika te onderneem. In die lig van die opdrag van die 67 ste $\mathrm{AKV}$, is daar gesprek gevoer oor die vereistes vir die herstel van die NHKA se lidmaatskap van WARC en die mate waarin die NHKA daaraan voldoen het.

Net voor die 68ste AKV van die NHKA het die Kommissie van die AKV 'n Herderlike Brief 2007 aan die gemeentes van die Kerk gestuur. Die titel van die brief was 'Identiteit en Relevansie van die Kerk in die 21ste eeu' (NHKA 2007b:1). Die informele en nie-amptelike nadenke oor die NHKA wat tydens die Nasionale Colloquium plaasgevind het, is hierdeur geformaliseer. Die gewigtigheid van die dokument blyk uit die feit dat die Herderlike Brief ' $n$ bepaalde status en gesag het (teenoor ' $\mathrm{n}$ samespraak soos die Colloquium). In Ordinansie 5.5.1 staan juis dat herderlike briewe beredeneerde standpunte oor aangeleenthede wat vir die kerk van wesenlike teologiese belang is, bevat en verduidelik (NHKA 1997:87). Daar het dus weliswaar 'n denkverskuiwing plaasgevind. Dit het egter later geblyk dat hierdie verskuiwing net by ' $n$ gedeelte, in der waarheid 'n geringe meerderheid (51 persent), plaasgevind het.

Dít kom na vore in die Addendum tot die Agenda van die 68ste Algemene Kerkvergadering (NHKA 2007c), waar die na-binne gerigtheid van die NHKA sowel as etnies gedrewe klemtone ook steeds opgemerk word. Hierin verklaar die gemeente Poort dat die poging tot die verwydering van die volkskerkgedagte uit die Kerkorde geen teologiese gronde het nie en dat ' $n$ volkskerk op ' $n$ besondere manier moontlikhede bied om die Christelike getuienis en die Christelike diens op die wydste manier in die openbare lewe te laat deurwerk (NHKA 2007c:41). Die gemeente Tarlton betreur samewerking en vereniging met' 'n 'kerk wat 'n ander taal, kultuur, etiese - en morele waardes, ras, Bybelse beskouing en Godsbeskouing as ons het' (eie beklemtoning) (NHKA 2007c:8). Die mees oortuigende argument vir die na-binne gerigtheid van die NHKA word waarskynlik deur die opmerkings van die gemeente Utrecht geillustreer: 'Die voorgestelde wysigings aan die Kerkorde [sal] die wese van die NHKA ... raak, want dan sal die kerk oop wees vir almal' (eie beklemtoning; NHKA 2007c:13). Dít kom onomwonde op ' $\mathrm{n}$ eksklusiewe ekklesiologiese aard neer.

Laasgenoemde word net verder gerugsteun deur die beperkende aard van die NHKA se ekumeniese gerigtheid. Die kerk het ekumeniese verhoudinge (wat ook interkerklike samewerking behels) met slegs die NGK, die Gereformeerde Kerke van SuidAfrika (GKSA) en die Maranatha Reformed Church of Christ (MRCC).

Wat die ekumene van die NHKA met voormelde eerste twee, Afrikaanssprekende kerke betref, bestaan die ekumeniese relasie tussen hulle bloot uit 'georganiseerde samesprekings tussen die drie kerke' (NHKA 1991:74). Die inhoud van hierdie samesprekings is debatvoering oor aksentverskille in die verstaan van die begrip kerkwees en hoofsaaklik oor die wyse waarop kerkeenheid gerealiseer behoort te word (Geyser 1999:315; vgl Van Wyk \& Buitendag 2008:1467). Die NHKA het telkens geargumenteer dat eenheid in waarheid nie tot een denominasie hoef te lei nie ('Historiese Agtergrond van die TKK', in NHKA 1991:74).

Die enigste ander kerk waarmee die NHKA ekumeniese bande het, is die sogenaamde 'dogterkerk' van die NHKA, naamlik die MRCC. Beyers (2007:2) verklaar dat daar tot op hede twee benaderingswyses was wat gegeld het vir die verhouding tussen die NHKA en die MRCC. Eerstens was daar 'n ekumeniese verhouding, met die gedagte dat die NHKA en die MRCC twee afsonderlike volkskerke is wat afsonderlike kulture en volke bedien en waarin ekumeniese kontak genoegsaam was, sonder om oor kerkeenheid te besin. Hierdie ekumeniese verhouding het egter ten nouste verband gehou met die tweede benaderingswyse tot die verhouding tussen die twee kerke, synde ' $n$ missionêre verhouding waarin die MRCC (voorheen die Hervormde Kerk van Suid-Afrika, oftewel HKSA) as die vergestalting van die sendingbeleid van die NHKA beskou is (Beyers 2007:3; vgl Dreyer 2006). In die aanloop tot die 68ste $\mathrm{AKV}$ het Beyers egter die konvergensie van hierdie twee benaderingswyses voorgestel, wat daarop neerkom dat die MRCC nie meer as sending-objek nie, maar eerder as die sendingvennoot van die NHKA beskou word (Beyers 2007:3).

Teenoor die teologiese denkwyse wat die volkskerklike, eksklusiewe aard van die NHKA beklemtoon, het die Hervormde Dosentevergadering van die Fakulteit Teologie aan die Universiteit van Pretoria positiewe kommentaar gelewer op die Kommissie van die AKV se beskrywingspunt dat die 68ste AKV die begrip 'volkskerk' uit die Kerkorde moet haal.

In die Dosentevergadering se studiestuk word verklaar dat die NHKA op grond van teologiese worsteling behoort te erken dat 'n Bybels-teologiese regverdiging van 'n politieke ideologie soos Apartheid nie aanvaar kan word nie en dat die begrip volkskerk in eietydse apostolaat en kerkwees agterhaal is. Die gronde wat onder andere hiervoor aangebied word, was die volgende:

Enige teologie wat in sy kerkbegrip iets anders soos die natuur (kultuur, taal, tradisie, volk) verreken, (is) problematies .... Dit kom neer op die verburgerliking van die evangelie, terwyl geloof in Christus alleen konstitutief vir lidmaatskap van die kerk is. In die begrip volkskerk word twee genera met mekaar vermeng en word die kerk 'van bo' (genade) en 'van onder' (natuur) verstaan. Daarmee word veronderstel dat die raakvlak tussen God en mens nie' $n$ saak van die geloof is nie, maar wel een van die natuur en dat daar beide in die Ou Testament en die Nuwe Testament profetiese kritiek teen die sakralisering van die natuur-en volkslewe aangetref word.

(NHKA 2007d:342-348)

Op 12 Maart 2009 reik vyf Teologiedosente ${ }^{8}$ van die NHKA ' $n$ verklaring getiteld 'Apartheid in Kerk en Politiek' uit (NHKA 2009). Buiten in Beeld van 13 Maart 2009, is dit ook op die webwerf www.teo.co.za ${ }^{9}$ gepubliseer en het wyd reaksie ontlok, veral vanuit die geledere van die NHKA. Daarin verklaar die dosente 'as predikante van die NHKA ... dat Apartheid sowel in uitwerking as in wese sonde is en enige teologiese regverdiging daarvan ... 'n mistasting [is]' (NHKA 2009). In die e-Hervormer van 19 Maart 2009, 'n amptelike mondstuk van die NHKA in elektroniese vorm, het die voorsitter van die Algemene Kommissie van die AKV egter verklaar dat die dosente se verklaring 'voortydig en onnodig' was en benadruk hy opnuut die besluit van die 68ste AKV dat 'dit nie op die weg van die Algemene Kerkvergadering lê om politieke beleide goed of af te keur nie' (kyk NHKA 2009; vgl NHKA 2007a:104).

Die gevolgtrekking is dat dieNHKA in die verlede én steeds in die hede telkens die Kerk aan die hand van die Kerk se volkskerklike teologie (ideologie?; vgl Wolff 2006) identifiseer en dat hierdie verstaan die grondslag vir die bepaling van wie (watter persone)

8.Proff. Johan Buitendag, Yolanda Dreyer, Ernest van Eck, Andries van Aarde en James-Alfred Loader.

9.http://www.teo.co.za /fakulteit/apartheid in kerk en politiek 
en op grond waarvan persone in die geloofsgemeenskap van die NHKA ingesluit word. Vanuit die geskiedenis van die NHKA is dit duidelik dat die indikatiewe aard van die dimensies of karaktertrekke (soos hier bo na verwys is) van veral eenheid en katolisiteit wel deeglik mee rekening gehou is. In hierdie sin was dit helaas statiese konsepte. Die imperatiewe aard van eenheid en katolisiteit is egter nooit volledig verreken nie. Dit is nie as dinamiese werklikhede beskou nie. Hieruit blyk dat die NHKA sake soos kultuur, taal, volk en tradisie as konstitutief vir lidmaatskap van die Kerk beskou, ${ }^{10}$ teenoor die sola gratia, sola fide en sola Scriptura, wat in die Solus Christus saamgevoeg word. ${ }^{11}$

\section{DIE NHKA SE VERSTAAN EN HANTERING VAN HOMOSEKSUEEL GEORIËNTEERDE PERSONE}

Op die Moderamenvergadering van 26 Januarie 2001 het ds J.F. van $\mathrm{Zyl}$ van die NHKA die Kommissie van die AKV meegedeel dat hy homoseksueel is. ${ }^{12}$ Hy het in daardie stadium in Wesmootgemeente gewerk, met sy vrou, dr S.M. van Zyl (tans De Beer), as medeleraar. Die kwessie oor sy voorafgaande bedieningswerk binne die NHKA was onmiddellik ter sprake (NHKA 2001:13). In die notule van die gewone vergadering van die Kommissie van die AKV op 15 en 16 Maart 2001 word gestel dat Van Zyl aanvanklik met sy bediening wou voortgaan:

Ek voel nie dat seksualiteit ' $n$ keuse is nie ... ek glo soos altyd dat die Here vir my baie gawes en talente gegee het wat ek tot groot vrug in my predikantsamp kan aanwend. In die lig van my geroepenheid, asook die feit dat daar nie van enige wangedrag sprake is nie, wil ek die Kommissie vra om dit asseblief te oorweeg dat ek my predikantsamp mag behou.

(NHKA 2001:14)

In 'n koerantonderhoud (Jackson 2002) verklaar Van Zyl: 'Die kerkleiers het my laat kom en gesê gay predikante is nie vir die kerk aanvaarbaar nie.' Hierdie stelling deur Van Zyl sowel as sy koerantonderhoud sou as sy subjektiewe ervaring van die Kerk se optrede teen hom afgemaak kon word. Op dieselfde bladsy van die koerant verskyn egter ' $n$ verklaring deur die destydse voorsitter van die Algemene Kommissie van die AKV wat Van Zyl se stelling staaf:

Kerkbesluite van die AKV kom daarop neer dat die persoon van homoseksueel nie veroordeel word nie, dat daar met liefde en begrip met sulke persone gehandel word, maar tegelyk dat die homoseksuele praktyk nie deur die kerk goedgekeur kan word nie. Dit het die noodwendige konsekwensie dat dit nie met die predikantsamp te rym is nie.

(Jackson 2008a)

Dus het Van Zyl ná gesprekvoering met die destydse leierskap van die Kommissie van die AKV besluit om van lewenstaat te verander (NHKA 2001:13) en is hy gevolglik ingevolge Ordinansie 2.1.13.3 van sy amp onthef. In dieselfde notule as waarna hier bo verwys word, word gestel dat Van Zyl tydens die vergadering met die Kommissie van die AKV te kenne gegee het dat hy nie in ' $n$ homoseksuele verhouding betrokke is nie.

10. Hierdie terme word hier weer met erkenning aan die Dosentevergadering gebruik.

11.Op die 68ste AKV van die Hervormde Kerk is daar met 51 persent teenoor 49 persent ten gunste van die verwydering van die woord 'volkskerk' uit die huidige Kerkorde van die NHKA gestem. Dit kon egter nie verander word nie, want volgens die Kerkorde kan 'n besluit van hierdie aard slegs op grond van n tweederdemeerderheid stemme deurgevoer word (Ordinansie 10.1; NHKA 1997:112). Dít getuig van die begin van die denkverskuiwing én groeipyne in die Kerk. Presies in watter mate (hoeveelheid) die denke verskuif het en watter invloed hierdie 'verskuifde denke' gehad het, sal eers teen die 69ste AKV vasgestel kan word, veral in die lig daarvan dat die beskrywingspunt oor "versoenende verskeidenheid", soos vervat in die Agenda van die 68ste AKV, nooit ter tafel verske 'o aanvaar is nie (NHKA 2007a:46).

12.Die inligting oor mnr J.F. van Zyl en dr S.M. de Beer word met albei se medewete en goedkeuring by hierdie artikel ingesluit.
Verderaan in daardie notule word gesuggereer dat die besluit om sy huwelik te beëindig moontlik ' $n$ bewuste besluit van Van Zyl was om wél homoseksueel aktief te raak (NHKA 2001:15).

Tesame met sake soos kultuur, taal, volk en tradisie, blyk uit die bestudering van hierdie studiegeval dat ook die mens se seksualiteit, oftewel seksuele oriëntasie, in die NHKA as wesenlik vir lidmaatskap beskou word, aangesien die voorregte van lidmaatskap van die gemeenskap van gelowiges - die bediening van en deelname aan die sakramente sowel as toelating tot die ampte - op grond van sy seksualiteit van Van $\mathrm{Zyl}$ ontneem is.

Die 66ste AKV van 2001 het ' $n$ beskrywingspunt goedgekeur dat ' $\mathrm{n}$ studiekommissie benoem word om homoseksualiteit as verskynsel te ondersoek, om sodoende die 67ste AKV van September 2004 daaroor in te lig en te adviseer. Die 67ste AKV het van die studie kennis geneem en die resultate van die studie én nog ' $n$ bykomende studie vir bespreking na die 68ste AKV in 2007 verwys. Tydens die 68ste AKV is bepaalde beskrywingspunte vir oorweging aan die vergadering voorgelê. Uittreksels daaruit lui soos volg:

Die norm van die Skrif is dat alle gelowiges uit die evangelieboodskap leef. In die Protestantse kerk is die vertrekpunt dat redding berus op geloof alleen. Niks vanuit die menslike natuur kan hierdie versoening bewerkstellig nie. God se Gees maak dit vir alle gelowiges moontlik om hulle hele lewe (ook die liggaam) in God se diens te stel.

Die kerk glo dat alle gedooptes, alle gelowiges, lede van die liggaam van Christus is. Die eenheid van die kerk as liggaam van Christus is ' $n$ evangeliese eis. Derhalwe is mense wat tot seksuele minderheidsgroepe (of tot watter minderheidsgroepe ook al) behoort, soos alle ander lidmate, welkom in die Christelike geloofsgemeenskap.

(NHKA 2007d:45-46)

Die 68ste AKV het nie die beskrywingspunt van die studiekomitee oor homoseksualiteit aanvaar nie. Die saak is weereens vir studie en besluitneming na die 69ste AKV verwys.

\section{SLOTOPMERKINGS}

Die term 'homoseksualiteit' was aanvanklik 'n patologiserende mediese term (Foucault [1978] 1990:1-13; vgl Rogers 2006:127; Dreyer 2006:459). Heteroseksualiteit was die norm en enigiets wat daarvan verskil het, was noodwendig afwykend en siek. 'n Ondersoek van die National Gay Task Force in 1984 het bevind dat 90 persent van mans en 75 persent van vroue as gevolg van hul seksuele oriëntasie verbaal geteister is. Dit illustreer die bevooroordeelde houdings en gedrag van die meerderheid en dui op homofobie - ' $n$ intellektueel ongegronde vrees vir homoseksualiteit wat tot uiting kom in negatiewe emosies en lei tot diskriminerende gedrag teenoor persone wat homoseksueel georiënteerd is (Müller 2008:470). Op sy beurt verklaar Kantor (1998:6-7) dat daar ' $n$ verband bestaan tussen homofobie en rassisme, anti-Semitisme en xenofobie, aangesien al hierdie sake met vooroordeel teenoor gevestigde paradigmas oor wat die norm is, verband hou (kyk ook Blumenfeld 1992; Dreyer 2006).

Daar blyk inderdaad ook wat die NHKA se ekklesiologie aanbetref 'n verband in die Kerk tussen die verstaan en hantering van homoseksualiteit en die beklemtoning van ras te wees. Die na- binne gerigtheid van die NHKA, soos dit voorkom in die volkskerklike denke en in die ondersteuning van Apartheid; die verstaan van eenheid en katolisiteit en soos dit voorkom in die NHKA se verhoudings met ander kerke, kan nie anders nie as om neer te kom op 'n eksklusiewe ekklesiologie, oftewel 'n gekwalifiseerde inklusiwiteit ... waarbinne mense wat nié aan die vereistes van lidmaatskap, naamlik Blank, Afrikaans en heteroseksueel (oftewel selibate homoseksueel) voldoen nie, noodwendig uitgesluit word. Lidmaatskap word dus nie deur die sola fide bepaal nie, maar eerder deur die akkommodasie van die geloofsgemeenskap. Daar is verskeie teenstellings in die Kerk se ekklesiologie wat uiteindelik die Kerk se verstaan en 
hantering van homoseksuele persone beïnvloed en bepaal:

- Die NHKA erken en bely die eenheid van die kerk, maar is tevrede daarmee dat die eenheid tussen medegelowiges en medegedooptes onsigbaar bly en in die vorm van ' $n$ eksklusiewe ekklesiologie uitdrukking vind.

- Die NHKA erken en bely die katolisiteit van die kerk, maar laat nie die moontlikheid oop dat verskillende minderheidsgroepe (ook seksuele minderheidsgroepe) onder die koepel van versoenende verskeidenheid in die Kerk 'n tuiste kan vind nie.

- Die NHKA erken en bely die heiligheid van die kerk en dat hierdie heiligheid nie op Donatistiese wyse van gelowiges self afhang en in hulle gesetel is nie, maar maak steeds op grond van die heiligheid van die kerk daarop aanspraak dat homoseksueel georiënteerde persone, op grond van die sondige homoseksuele daad, nie al die voordele en voorregte verbonde aan volwaardige en volledige lidmaatskap mag geniet nie.

- Die Kerk erken en bely die apostolisiteit van die kerk, maar gebruik Matteus 28:16-20 om die konsep van die volkskerk in terme van die apostolêre gerigtheid van die NHKA te regverdig (kyk Van Aarde 2006:106).

Van Aarde beredeneer dat die wyse waarop die apostolisiteit van die Kerk verwesenlik word as 't ware die toetssteen is vir die imperatiewe verstaan van al die dimensies van kerkwees (vgl Käsemann 1963:145), aangesien dit oor die verstaan en hantering handel van diegene wat sogenaamd 'binne' en sogenaamd 'buite' die kerk is:

Die geloofwaardigheid van die apostolaat van die kerk, asook die kerk se strewe om ekumenies te wees, is in gedrang wanneer die kerk ' $n$ groot saak wil maak van uitreik na ander toe, maar nie in staat is om bereid te wees om diegene wat buite is, onvoorwaardelik te sien as potensieel saam met jou in die kerk nie - wat die saam aansit aan die nagmaalstafel insluit ... dit vra om die Ander insluitende die straatkind, die prostituut, die anders-biologies geskape en anders-seksueel georiënteerde, die anders-volkige, die anders-kleurige, die anders-godsdienstige nie as onaanvaarbaar vir inkom in die kerk in die kerk te beskou nie, omdat hulle nie is soos $j y$ is of is soos jy wil hê hulle moet wees nie.

(Van Aarde 2006:107)

Die aard en omvang van die kerk behels dus almal wat die belydenis deel dat God in en deur Jesus van Nasaret God-by-ons is, mits dié belydenis insluit om ook te dóén wat Jesus in liefde gedoen en geleer het. As die NHKA deur die onderskrywing van die verbondsteologie, die kinderdoop en die 'gestuurdheid' van die kerk (kyk NHKA 1997) bely dat alle gedooptes lede van die liggaam van Christus is en een is in Christus op grond van God se sola gratia, volg dit dat homoseksueel georiënteerde mense nie as gevolg van hul seksuele oriëntasie van die geloofsgemeenskap uitgesluit mag word nie (kyk Dreyer 2004:201). Dit volg ook dat hulle, saam met alle ander mede-lede van die liggaam van Christus, ook geregtig is op alle voorregte wat genoemde lidmaatskap inhou: die gemeenskap met gelowiges (saam bid, saam werk, saam lewe); deelname aan die Nagmaal en deelname aan die ampte van die kerk.

In teenstelling met 'n eksklusiewe ekklesiologie wat op etniese (kultuur-) verskille en sogenaamde natuurverskille berus, is die imperatiewe inklusiwiteit as evangelie duidelik. Burridge (2007) betoog soos volg:

Whenever we are presented with a choice between being biblical and being inclusive, it is a false dichotomy - for to be truly biblical is to be inclusive in any community which wants to follow and imitate Jesus'.

(Burridge 2007:409)

Die NHKA bely immers ook die sola Scriptura. Volgens Van Eck (2009:8) is die inklusiwiteit self die evangelie (die goeie nuus). Jesus het deurgaans God as 'inklusiewe God' verkondig. As medelidmate van die liggaam van Christus is dit gevolglik elke gelowige se taak om met betrekking tot die inklusiwiteit wat Jesus verkondig het, Jesus in elke opsig daarvan na te boots
(Burridge 2007). Die Hervormde kerk, as selfbelyde kerk van Christus, kan dus nie anders as om ook 'n God te verkondig wat alle grense deurbreek en elke individu se waarde belangrik ag. Dít beteken inderdaad ' $n$ kerk wat 'oop is vir almal'.

\section{LITERATUURVERWYSINGS}

Barth, K., 1947, 'Die Kirchliche Lehre von der Taufe' [Die kerklike leer van die doop], Theologische Studien 14, 3-48

Barth, K., 1949, Dogmatics in Outline ['n Bloudruk van die Dogmatiek], transl. G.T. Thomson, SCM Press, London.

Barth, K., 1963, Evangelical Theology. An introduction [Evangeliese Teologie. 'n Inleiding], Weidenfeld and Nicholson, London.

Barth, K., 1967, 'Die Taufe als Begründung des christlichen Lebens [Die doop as ' $\mathrm{n}$ regverdiging van die Christelike lewe]', in K. Barth (Hrsg.), Die kirchliche Dogmatik IV, 4, n.p., EVZ-Verlag, Zürich.

Bellis, A.O., 2002, Science, Scripture and homosexuality [Wetenskap, die Byble en homoseksualiteit], The Pilgrim Press, Cleveland, $\mathrm{OH}$.

Beyers, J., 2007, 'Die verhouding tussen die NHK en die MRCC', referaat gelewer op die inligtings- en besprekingsvergadering, NHK Montana, Pretoria, 14 Februarie.

Blumenfeld, W.J., 1992, Homophobia: How we all pay the price [Homofobie: Hoe ons almla die prys betaal], Beacon Press, Boston, MA.

Bosch, D.J., 1991, Transforming mission: Paradigm shifts in theology of mission [Transformasie van sending: Paradigma verskuiwings in die teologie van sending], Orbis Books, New York.

Botma, M.A., 1996, "n Krities-realistiese ondersoek na die verskynsel pluraliteit-eenheid van die Kerk', ongepubliseerde DD-tesis, Universiteit van Pretoria.

Breytenbach, A.P.B., 1984, 'Verbond en verbondstekens in die Ou Testament - 'n terreinverkenning', HTS Teologiese Studies/ Theological Studies 40(3), 4-13.

Buitendag, J., 2006, 'Nuwe wyn in nuwe sakke en die behoud van altwee: 'n Herbedinking van die Hervormde Kerk se identiteit aan die begin van die 21ste eeu in SuidAfrika', HTS Teologiese Studies/Theological Studies 62(2), 343-362.

Buitendag, J., 2007, 'Openingsrede by die opening van die 68ste AKV van die NHKA', ongepubliseerde toespraak, Die Aula, Universiteit van Pretoria, Pretoria, 23 September.

Buitendag, J., 2008, 'Ecclesia reformata semper reformanda - die ongemaklike eis', HTS Teologiese Studies/Theological Studies 64(1), 123-138.

Burridge, R.A., 2007, Imitating Jesus: an inclusive approach to New Testament Ethics, Eerdmans Publishing Company, Grand Rapids.

Craffert, P., 2008, '(Im-)morele misleiding: bewoording van verskoning wys dis nie gemeente se oortuiging nie', Beeld, 16 September, p.11

Dreyer, T.F.J., 1999, 'Hervormde Etos en die roep om Spiritualiteit', in D.J.C. van Wyk jnr (red.), 20 ste eeu Hervormde Teologie, pp. 449-461, Sentik, Pretoria.

Dreyer, W.A., 1999, Nederduitsch Hervormde Kerk van Afrika: Die eerste 250 jaar 1652 tot 1902, Kital, Pretoria.

Dreyer, W.A., 2006, 'Die Nederduitsch Hervormde Kerk van Afrika as volkskerk: Oorsig en herbesinning', HTS Teologiese Studies/Theological Studies 62(4), 1337-1368.

Dreyer, Y., 2004, 'Homoseksualiteit: Die kerk, die tradisie en die Bybel - homofobie en sarkofobie en die evangelie', HTS Teologiese Studies/Theological Studies 60(1\&2), 175-205.

Dreyer, Y., 2006, 'Heteronormatiwiteit, homofobie en homoseksualiteit - 'n roetekaart vir 'n inklusiewe kerk', HTS Teologiese Studies/Theological Studies 62(2), 445-471. 
Dunn, J.D.G., 2008, 'One church - Many churches [Een kerk baie kerke]', in Einheit der Kirche im Neuen Testament, Dritte europäische orthodox-westliche Exegetenkonferenz, WUNT 218, Sankt Petersburg, Deutschland, August 24-31, 2005, pp. 3-23.

Eichrodt, W., 1961, Theology of the Old Testament [Teologie en die Ou Testament], vol. I, SCM Press, London.

Engelbrecht B.J., 1983, 'Verband tussen doop en verbond mag nie deurgesny word nie', Die Hervormer 75(8), 1.

Finaert, G. (ed.), 1968, 'Contra Cresconium, IV.xxi.26', in Oevres de Saint Augustin, vol. 31, n.p., Desclée, Paris.

Foucault, M., [1978] 1990, History of sexuality: An introduction [Geskiedenis van seksualiteit: 'n Inleiding], vol. 1, transl. R. Hurley, Random House, New York.

Germond, P., 1997, 'Heterosexism, homosexuality and the Bible [Heteroseksime, homoseksualiteit en die Bybel] ', in P. Germond \& S. De Gruchy (eds.), Aliens in the household of God: Homosexuality and Christian faith in South-Africa, pp. 188-232, David Phillip, Cape Town

Geyser, P.A., 1999, 'Gesprek met ander kerke', in D.J.C. Van Wyk (ed.), 20ste eeu Hervormde Teologie, pp. 314-319, Pretoria, Sentik.

Geyser, P.A., 2002, 'Bybelse getuienis oor homoseksualiteit - met ander oë gesien', HTS Teologiese Studies/Theological Studies 58(4), 1655-1677.

Jackson, N., 2008a, Kerk moet aanvaar mens kies nie om gay te wees', Beeld, 22 Junie, p. 12.

Jackson, N., 2008b, 'Boesak bedank oor Belhar', Beeld, 04 Oktober, p. 2.

Jonker, W.D., 1994, Bevrydende waarheid, Hugenote Uitgewers, Wellington.

Kantor, M., 1998, Homophobia: Description, develepmont and dynamics of gay bashing [Homofobie: Beskrywing, ontwikkeling en dinamika van homoseksuele aanrandingl, Praeger Publishers, Westport.

Kärkkäinen, V.M., 2002. An introduction to ecclesiology: Ecumenical, historical and global perspectives ['n Inleiding to ekklesiologie; Ekumeniese, historiese en globale perspektiewe], Intervarsity Press, Downers Grove, IL.

Käsemann, E., 1963, 'The church, its unity, holiness and universality [Die kerk, sy eenheid, heiligheid en universaliteit]', Novum Testamentum 6, 141-148.

König, A., 1971, 'Karl Barth se finale verwerping van die kinderdoop', Theologia Evangelica 4(1), 44-45.

König, A., 1983, 'Die kinderdoop en die genadeverbond', ongepubliseerde voordrag voor ' $n$ teologiese kongres oor die kinderdoop, Universiteit van Suid-Afrika, Pretoria, 03-05 Oktober.

Kritzinger, J., 2008, 'Belhar op papier - niks', Beeld, 12 November, p. 15.

Küng, H., [1968] 2001, The church [Die kerk], Burns and Oats, London.

Masango, M., 2002, 'Homosexuality: A challenge to African churches [Homeseksualiteit: 'n Uitdaging aan Afrikaanse kerke]', HTS Teologiese Studies/Theological Studies 58(3), 957-972.

McGrath, A.E., 2001, Christian Theology: An introduction [Christelike Teologie: 'n Inleiding], Blackwell, Oxford.

Moltmann, J., 1993, The church in the power of the Spirit [Die kerk in die krag van die Gees], Minneapolis, MN.

Müller, J.C., 2008, Christelike Kern-ensiklopedie, red. F. Gaum, Lux Verbi, Wellington.

Nederduitsch Hervormde Kerk van Afrika (NHKA), 1951, Kerkwet van die Nederduitsch Hervormde Kerk van Afrika, Kerkargief, Pretoria.

NHKA, 1973, Herderlike skrywe van die AKV van die NHKA aan die lidmate van die kerk oor sy opvatting met betrekking tot volkereverhoudings in die RSA, Algemene Kerkvergadering, Nederduitsch Hervormde Kerk van Afrika, Kerkargief, Pretoria.
NHKA, 1985, Kerk en wêreld 2000, Nederduitsch Hervormde Kerk van Afrika, Kerkargief, Pretoria.

NHKA, 1990, Kerk en politiek, Nederduitsch Hervormde Kerk van Afrika, Kerkargief, Pretoria.

NHKA, 1991, Resultate van die TKK. Handelinge van die Afvaardiging van die NG Kerk, die NH Kerk en die Gereformeerde Kerke in Suid-Afrika Januarie 1991-Desember 1993, Nederduitsch Hervormde Kerk van Afrika, Kerkargief, Pretoria.

NHKA, 1997, Kerkorde van die Nederduitsch Hervormde Kerk van Afrika, Algemene Kerkvergadering, Nederduitsch Hervormde Kerk van Afrika, Kerkargief, Pretoria.

NHKA, 2001, Agenda/besluitebundel van die 66ste Algemene Kerkvergadering, bylae F, Nederduitsch Hervormde Kerk van Afrika, Kerkargief, Pretoria.

NHKA, 2004, Agenda van die 67ste Algemene Kerkvergadering, Kommissie van die AKV, Nederduitsch Hervormde Kerk van Afrika, Kerkargief, Pretoria.

NHKA, 2007a, Besluitebundel. 68ste Algemene Kerkvergadering, Kommissie van die AKV, Nederduitsch Hervormde Kerk van Afrika, Kerkargief, Pretoria.

NHKA, 2007b, Herderlike Brief 2007. Identiteit en Relevansie van die Kerk in die 21ste eeu, Kommissie van die AKV, Nederduitsch Hervormde Kerk van Afrika, Kerkargief, Pretoria.

NHKA, 2007c, Addendum tot die Agenda van die 68ste Algemene Kerkvergadering, Kommissie van die AKV, Nederduitsch Hervormde Kerk van Afrika, Kerkargief, Pretoria.

NHKA, 2007d, Agenda van die 68ste Algemene Kerkvergadering, Kommissie van die AKV, Nederduitsch Hervormde Kerk van Afrika, Kerkargief, Pretoria.

NHKA 2009, 'Apartheid in kerk en politiek', e-Hervormer, 19 Maart 2010, toegang verkry op 22 Junie 2010, van https:// www.ehervormer.co.za/argief.

Newbigin L., 1952, Household of God [Huishouding van God], SCM Press, London.

Pelser, G.M.M., 1994, 'Enkele opmerkings oor die wese van kerk', HTS Teologiese Studies/Theological Studies 50(1\&2), 311-329.

Pont, A.D., 1981, Die historiese agtergronde van ons kerklike reg, deel I, HAUM, Pretoria.

Rogers, J., 2006, Jesus, The Bible and Homosexuality: Explore the myths, heal the Church [Jesus, die Bybel en Homoseksualiteit: Verken die mites, genees die kerk], Westminster John Knox Press, Louisville, KY.

Schlink, E., 1972, The doctrine of Baptism [Die leer van die doop], transl. H. Bouman, Concordia Publishing house, Saint Louis, MO.

Seitz, C., 2000, 'Sexuality and Scripture's plain sense: The Christian community and the law of God [Seksualiteit en die duidelikheid van die Skrif: Die Christelike gemeenskap en die wet van god]', in D.L. Balch (ed.), Homosexuality, science and the 'plain sense' of Scripture, pp. 177-196, Eerdmans, Grand Rapids, MI.

Seow, C.L., 1996, 'Textual orientation [Tekstuele oriëntasie]', in R.L.Brawley (ed.), Biblical ethics \& homosexuality, pp. 17-34, Westminster John Knox, Louisville, KY.

Tofana, S., 2005, 'Die Beziehung zwischen der lokalen und universalen Kirche [Die verhouding tussen die plaaslike en universiële kerkl', in Einheit der Kirche im Neuen Testament, Dritte europäische orthodoxwestliche Exegetenkonferenz, WUNT 218, Sankt Petersburg, Deutschland, 24-31 August.

Van Aarde, A.G., 1984, 'Die verbondstruktuur in die Nuwe Testament - 'n terreinverkenning met die oog op die debat oor die verhouding kinderdoop-verbond', HTS Teologiese Studies/Theological Studies 40(3), 28-55.

Van Aarde, A.G., 1987, 'Gedagtes oor die begin van die kerk - 'n geskiedenis van versoenende verskeidenheid', HTS Teologiese Studies/Theological Studies 43(3), 325-351.

Van Aarde, A.G., 2006, 'Hoe om in te kom en hoe om binne te bly - die "groot sendingopdrag" aan die kerk vandag volgens Matt 28:16-20', HTS Teologiese Studies/Theological Studies 62(1), 103-122. 
Van der Merwe, P.J. 1990, ‘Die Nederduitsch Hervormde Kerk en sy bediening in ' $n$ toekomstige Suid-Afrika: Die visie van Kerk en Wêreld 2000', HTS Teologiese Studies 46(4), 672-689.

Van Eck, E., 2009, 'Inklusiwiteit as evangelie', HTS Teologiese Studies/Theological Studies 65(1), Art. \#304, 10 pages. DOI: 10.4102/hts.v65i1.304

Van Wyk, D.J.C. (jnr),1999, 20ste eeu Hervormde Teologie, Pretoria, Sentik.

Van Wyk, T. \& Buitendag J., 2008, 'Die dimensies van 'eenheid' en 'katolisiteit' in die Nederduitsch Hervormde Kerk sedert Ottawa 1982', HTS Teologiese Studies/Theological Studies 64(3), 1447-1473.
Visser, L.L.J., 1958, 'Die verbond in die teologie van Karl Barth', ongepubliseerde doktorale proefskrif, Departement Sistematiese Teologie, Universiteit Stellenbosch

Waetjen, H.C., 1996, 'Same-Sex relations in Antiquity and Sexuality and Sexual Identity in contemporary American Society [Homoseksualiteit in die oertyd en seksualiteit en seksuele identiteit in die hedendaagse Amerikaanse samelewing]', R.L Brawley (ed.), Biblicalethics E homosexuality, pp. 87-102, Westminster John Knox, Louisville.

Wolff, E., 2006, 'Die anatomie van 'n teologiese ideologie: Die Hervormde Kerk se steun aan die Apartheid Ideologie', Historia 51(1), 141-162. 